\title{
O. P. Bhatnagar's Clarion Call to Reform Indian English Poetry
}

\author{
Dr. Ananta Geetey Uppal
}

Associate Professor, Humanities \& Social Sciences, Galgotias University, Greater Noida, UP

\begin{abstract}
O.P. Bhatnagar is an original poet expressing and asserting his originality of imagination, conception and treatment. He has also kept himself aloof from the dominant schools of poetry and attempts to function close to the centre of society without self-accusation and morbidity characteristic of modern poetry. While dealing with the complexity he tends to keep a delicate grasp of the world around him. His mission is to discover truth without self-indulgent esotericism. Above all, Bhatnagar is a true humanist who has been endeavoring all his life to ameliorate the status and raise the dignity of man in modern world dominated by the hawks and hyenas of politics. This paper iterates Bhatnagar's clarion call to modern Indo English poets to stop window dressing, environment reporting, and start bringing poetry within the reach of the common man.
\end{abstract}

Keywords-Modern poetry, truth, humanity, politics, society.

As the most authentic portrayer and interpreter of human life, as a champion of the underprivileged in the Indian social structure, as a compassionate lover of mankind, as a relentless fighter against orthodoxy, exploitation, corruption, moral degeneration and hypocrisy, as a creator of the exquisite poetry of life, as a critic of poetry, and Indian literature in English, as a glorifier of the status of Indian poetry in English, and as a spokesman of the conscience of mankind, O.P.Bhatnagar occupies a unique place in contemporary Indian literature in English. $\mathrm{He}$ is a contemporary of such Indian poets writing in English as P.Lal, Nissim Ezekiel, Keki N. Daruwalla, Krishna Srinivas, Shiv K. Kumar, Jayant Mahapatra, R. Parthasarathy, Pritish Nandy, and Anand Coomaraswamy. With his seven volumes of poems, three books of criticism, and twenty critical articles, Bhatnagar has given new dimensions to Indian poetry in English.

Indian poetry in English has come to exist. According to the existential theory "existence precedes essence", Indian poetry must achieve its essence as it has come to exist. It must shine like a bright star on the firmament of Indian literature in English. In his introduction to The New Dimensions in Indo-English Poetry, Bhatnagar voices a passionate plea for developing an authentic character of poetry by extracting its sustenance from its surroundings. He further says that new Indo-English poets must feel free and strong enough to produce original poetry from their own experiences.
Bhatnagar firmly believes that individuality is an essential tenet of poetic creation. Returning to tradition mars one's individual talents. He therefore contends "......one who goes back to tradition loses his/her individual talents and surrenders some part of truth, integrity, vision and creativity". (Bhatnagar, 12) Like T.S.Eliot, Bhatnagar also uses tradition and individual talent, but in altogether a different framework. By tradition and individual talent Eliot means "that an individual discovers his or her true talent only by submerging it in tradition. Bhatnagar holds that individual talent shines only when it is separated from tradition. Indian poets should free themselves from the accumulated burden of the wisdom of the past and seek reality as it exists at present.

Bhatnagar is not a believer in Lockean theory insistence on the self as absolute reality. He says poetic creation consists of relationship between the self and its object. In Future Directions, Bhatnagar avers that poetry "has helped man to interpret and define the subtle interrelationships of the within with the without, of the outs inning and innings out." (Bhatnagar, 27) His poetry therefore insists on the originality of vision and creation.

Another significant trait of his poetry is that it is free from high-pitched philosophy, spiritualism, and religion which are commonly found in other Indo-English poets. It may be so because Bhatnagar's poetry is entirely focused on man.

Bhatnagar further asserts that a poet should be 
courageous enough to challenge and resist what is bad and assert the rightness of things. Hence, the new Indian poetry must deal with contemporary life and situation. It must wage constant war against social evils such as moral degeneration, corruption, and hypocrisy which corrode social life and institutions.

There are always some major events in the life of a writer which influence his writings and shape his future. Bhatnagar is no exception. Bhatnagar was not only a witness but also a victim of frequent bickering between his parents which never allowed them to be at peace with themselves. As a child he had to bear the wrath of his parents. He was ill treated, beaten and even scorched. Every attempt was made to crush his individuality. In his poetry, Bhatnagar universalizes the bitter experiences of his childhood and likens them to the suppression of humanity all the world over. The contraries of life of his parents engendered in him an ironic vision which he elaborately expresses in his poetry.

Although Bhatnagar rightly condemns religious hypocrisy, his negation of God as the supreme power governing the universe and his theory that it is not God but reason that permeates the universe, is questionable. Pursuing the existential philosophy, Bhatnagar insists on the awareness of the energy of the self which makes a man drag himself out of the mud and mire and enables him to exist in this world which, to use Lord Buddha's phrase; is "DukhaAlaya" (the abode of miseries).

Our freedom has lost its essence and substance. Even five decades of liberty has not improved our condition even a bit. The greatest challenge before the Indo- English poets today is to expose our age-long slavery to customs, politico-social culture, and stir our spirit to fight to recover the honour of everything human, and of human value. For example, in the poem "I have Promises to Keep" the poet is determined "To shake the universe.../ To keep my countrymen awake." ( Feelings Fossils, p.12.)

The choice before us is between religion and politics, whether we should seek salvation in heaven or physical welfare on the earth. The poet emphatically asserts : "The castles in heaven have to be demolished to build habitations here and now. How long can poetry go on deluding itself with utopias of religion, philosophy, and the promised land while crores of people groan in utter poverty, hunger, and prolonged death? The common man today has no voice and if at all, a narrow one between the temporary favours and permanent reconstruction. God does not listen to him anymore; politics frustrates his dreams. Let poetry give him a voice. Man in Nature, Man of Nature, Man for Nature cannot be the images proper for today, but the nature of human dignity and politics." (Bhatnagar, 3)

The poet voices this feeling in his poem "Of Art and the Oppressed" (Audible Landscape, p.37) and in "Poetic Impressions" (A.L.p.40). In these poems, the poet satirizes the apathy of the Indo-English poets towards the exploited and the oppressed. By implication the poet says that art can come to the rescue of the oppressed.

According to Bhatnagar, past and future are modes of evading truth. Hence, poetry must give up being elitist, sensational, rhetorical, and emotional. It must be serene and rational.

Bhatnagar's poetry assumes relevance today because of its subtlety of irony with which he views the entire situation. Highlighting his multi-dimensional vision, Mohanty observes ; "Bhatnagar's irony is bare, rapiersharp. It has tendency not only to mirror the gap between the forces of good and the forces of evil but also to assert how the former remain invincible. Some may assert that Bhatnagar is asserting a new moral bias for poetry. His note of irony does not stem from a conventionally biased attitude of a moralist; it emerges from a profoundly humanized heart. It is perhaps this human element that makes Bhatnagar's poetry deeply engaging and arresting. He firmly believes that poetry without this human concern is either a shadow or nothing." (Mohanty, 7)

In an interview, Bhatnagar reiterates his intention to make his poetry more human, more sympathetic without being shallow or sham: "Man can think individually and independently of any system; more importantly from a human point of view and respond to human situations in a sympathetic way. The secularity of modern sensibility and its concern for man in the present and its awareness of the human significance of life are some of its aspects I would like to incorporate in my work in future.” (Bhatnagar, 12)

Another distinct aspect of Bhatnagar's poetry is that it deals with the national calamity or catastrophe which do not stir many of his contemporary poets who according to him "are engrossed in themselves and their falsehood".

There are certain shortcomings in Bhatnagar's poetry, which to some extent under-rate his achievement. They are: his excessive preoccupation with socio-political issues, utter lack of nature poetry, disregard for God and religion, and an acute want of spiritual and philosophical treatment of higher and finer aspects and purpose of human life. As there is no end to the socio-political problems facing man today and no poet or writer can effectively curb them, excessive involvement with such issues may not find favour with critics. At the same time, it may be admitted that it is not easy to dismiss the poet who has emerged as a 
champion of man and has given conclusive proof of his undaunted faith in his efficacy of committed literature. His various preoccupations are important tributaries to his humanism and can be valued for their own sake. He suggests new premises for Indian poetry in English. Poetry expresses truth of probability rather than the truth of facts. He keenly realizes that Indian poetry in English deplorably lacks in social and human concerns. Bhatnagar praises Indian poetry in English for its variety and progressive nature. He again and again stresses that it must voice its protest against all the decadent traditions. It must integrate politics with aesthetics to emphasize human values.

\section{CONCLUSION}

Outlining the priorities for an Indian poet in English, Bhatnagar says that what Indian poetry in English needs most today is not social authenticity but poetic sincerity in expression. The greatest drawback of Indian poetry in English is its being descriptive rather than being evocative. "The poverty of Indian poetry in English, especially is the poverty of an intellectual vision and a point of view and a refusal to shift from the poetry of reflexes to the poetry of intellect and intellectual reflections." (Bhatnagar, 76) $\mathrm{He}$ therefore lays down that the young Indian poets ought to be saturated with everything from Greek tragic poetry to Beowulf, Vedic Hymns to Mahabharat, and Tulsidas to Tagore.

According to Bhatnagar, the true goal of poetry is to build better homes on this earth that castles in heaven. It is not necessary that every writer should begin writing on political, moral, and social themes, but a writer must project what he feels about these burning problems. Thus his clarifications on theory of poetry and poetic creed are succinct, logical, and frank.

\section{REFERENCES}

[1] Bhatnagar, O.P. Feeling Fossils. Dehradun: Paul Jacobson, 1977.

[2]

$$
\text { Publications, } 1988 .
$$

[3] _. (Ed.), Studies in Indian Poetry in English, Jaipur: Rachna Prakashan, 1981, p.12.

[4] _ . "Future Directions Indian Poetry in English", Studies in Indian Poetry in English, Jaipur: Rachna Prakashan, 1984, p.27

[5] _ (Ed.) Rising Columns: Some Indian Poets in English, Amravati: Popular Book Centre, 1982

[6] . in an interview with Dr. A. N. Dwivedi, "Articulating Poetry: Interview with O.P.Bhatnagar", The Vision and the Voice, G.P.Baghmar (ed.), Vol. III. p.76.

[7] Mohanty, Niranjan, Introduction to Considerations: Critical
Responses to O. P. Bhatnagar' Poetry, Behrampur: Poetry Publication, 1984, p.7 